\title{
Hátsó vállízületi instabilitás artroszkópos kezelése
}

\author{
DR. PAVLIK ATTILA, DR. HIDAS PÉTER
}

\section{ÖSSZEFOGLALÁS}

A hátsó vállizületi instabilitás artroszkópos kezelése az utóbbi években vált egyre népszerúbb és eredményesebb beavatkozássá. Az OSEI Sportsebészeti Osztályán 2009. július 1. és 2015. szeptember 30. között összesen 20 esetben történt vállizületi hátsó instabilitás miatt stabilizáló mútét. A mútét minden esetben artroszkópos labrum refixáció és tokplasztika volt, 6 esetben elülső és hátsó stabilizálás történt, 14 esetben izolált hátsó stabilizálás. A mútét során fontos lépés a hátsó artroszkópos behatolás pontos elhelyezése az ideális horgonyelhelyezés érdekében. Erre vonatkozóan több lehetőség is van, a standard hátsó portál elhelyezésének a módosítása vagy két hátsó behatolás alkalmazása. Az utánvizsgálat során a betegek szubjektív véleményét, a munkába és a sportba való visszatérést rögzítettük, a vállfunkció értékelését a Rowe instabilitás és az ASES pontrendszer segítségével végeztük el. A fizikális vizsgálat során vizsgáltuk a vállízület mozgásait, az apprehenziós és az addukció-berotációs tesztet, valamint a humerusfej transzlációját. Betegeinknél kétirányú röntgenvizsgálat is történt (valódi AP és axillaris felvételek). Az átlagos utánvizsgálati idő 37,7 hónap volt (9-74). Az utánvizsgált 14 betegből 13 sportoló volt. A Rowe pontrendszerrel vizsgálva a 14 betegből 11-nél kiváló, két betegnél jó, egy betegnél pedig közepes eredményt találtunk. Az ASES pontrendszerrel értékelve a vállfunkciót átlagosan 88 (67-100) pontot értek el betegeink. A 13 sportoló közül 6 (46\%) azonos szinten tudta folytatni sporttevékenységét. Az artroszkópos hátsó labrum refixáció eredményesen végezhető, de technikailag nehéz, nagy tapasztalatot igénylő beavatkozás. A sportolók a mútétet követően jó arányban tudtak visszatérni sportágukhoz.

\section{Kulcsszavak: $\quad$ Artroszkópia; Instabilitás; Sportsérülés; Vállizület;}

\section{A. Pavlik, P. Hidas: Arthroscopic treatment of posterior shoulder instability}

Arthroscopic treatment of the posterior shoulder instability has become more popular and effective in recent years. Between 01.07.2009 and 30.09.2015 20 stabilizations were performed because of posterior shoulder instability in the Department of Sports Surgery of the Hungarian Institute for Sports Medicine. The surgeries were arthroscopic posterior labrum repair and capsular plication in each case, anterior and posterior stabilization was performed in 6 cases whereas isolated posterior stabilization in 14 cases. During surgery the precise positioning of the posterior portal is an important step for the ideal insertion of the suture anchors. In this respect, there are several possibilities, modifying the standard posterior portal placement or using 2 different posterior portals. During the follow up study the subjective opinion of the patients and of those returning to work or sports were recorded, and the shoulder function was evaluated based on Rowe instability score and the ASES score. During the physical examination, we examined the movements of the shoulder joint, the apprehension and the adduction - internal rotation tests and the translation of the humeral head. Furthermore, we recorded our patients' $x$-ray pictures (true AP and axillary) as well. The average follow up period was 37.7 month (9-73). Out of the 14 patients 13 were athletes. There were 11 excellent, 2 good and 1 fair result from the 14 patients based on the Rowe score. Our patients achieved an average of 88 points (67-100) evaluated by ASES score. 6 of the 13 athletes $(46 \%)$ were able to return to their sports carrier at the same level. Even though the arthroscopic posterior labrum repair can be performed effectively, it is a technically difficult procedure, which requires great experience. A fair rate of the athletes was able to return to sport after surgery.

Key words:

Arthroscopy - Methods; Athletic injuries; Joint capsule - Surgery;

Joint instability - Surgery; Shoulder joint - Surgery; 


\section{BEVEZETÉS}

A vállízületi instabilitás a populáció mintegy $2 \%$-át érintő, viszonylag gyakori elváltozás, azonban a hátsó instabilitás ennél jóval ritkább, az összes eset mindössze 2-10\%-át teszi ki $(13,18,21,24)$. Az esetek egy részében multidirekcionális instabilitás részeként jelenik meg. A hátsó instabilitás diagnózisa és kezelése is sok esetben kihívást jelent az ortopéd sebész számára. A betegek két fó csoportba sorolhatóak: az egyik csoport nagy energiájú trauma hatására elszenvedett hátsó (elakadásos) ficamot szenved, míg microtraumák vagy krónikus túlterhelés révén alakul ki a recidív hátsó subluxációs betegcsoport $(5,19$, 24). Ez utóbbi leginkább fiatal sportolóknál fordul elő, krónikus túlterhelés vagy egyszeri trauma következtében jön létre és klinikailag változatos tünetekben, általában recidív subluxatiók vagy a kar bizonyos helyzetében bekövetkező fájdalom képében jelenik meg. Gyakori a kontakt sportágaknál és a fej feletti terhelést végzőknél, többnyire a sportoló nem észleli az ízület kimozdulásait, instabilitását. A panaszokat a terhelés közben jelentkező diszkomfort érzés és a hátsó válltáji fájdalom jellemzi, amely a kar előre nyújtott, addukált és berotált helyzetében jelentkezik és a hátsó labrum - tok - posterior glenohumeralis szalag sérülése következtében jön létre $(17,19,24)$. Eredménytelen konzervatív kezelés esetén az utóbbi években egyre nagyobb számban felismert kórkép az artroszkópos hátsó labrum - tok rekonstrukciója révén mútéttel egyre eredményesebben kezelhető $(2,6,15,16,19$, $22,24,26,27)$.

A jelen tanulmányban ismertetjük az általunk alkalmazott artroszkópos hátsó labrum refixáció technikáját, kezdeti tapasztalatainkat és összefoglaljuk a mútéttel elért korai eredményeinket.

\section{ANYAG ÉS MÓDSZER}

Az OSEI Sportsebészeti Osztályán 2009. július és 2015. szeptember között összesen 20 esetben végeztünk vállízületi hátsó instabilitás miatt stabilizáló mútétet. Betegeink a mútétet megelőzően legalább 6 hónapos konzervatív kezelésen estek át, ami gyógytornász vezetésével végzett izomerősítő és propriocepciót javító gyógytornából állt. Ennek eredménytelensége esetén javasoltunk mútéti kezelést. Minden alkalommal artroszkópos beavatkozás történt, egy betegnél a mútét során fellépő technikai nehézségek miatt nyitott mútéttel fejeztük be a beavatkozást. Hat esetben elülső és hátsó stabilizálás történt, míg 14 esetben izolált hátsó stabilizálás, melyek közül két esetben hátsó dominanciával rendelkező multidirekcionális instabilitás esetében történt a hátsó stabilizálás.

A 20 beteg közül 7 volt férfi, 13 nőbeteg, 16 esetben a jobb, 4 esetben a bal vállat operáltuk, 14 betegnél a domináns oldal volt érintett. A betegek átlagéletkora a mútét időpontjában 19,8 év (14-35) volt. Az anamnézisben 15 betegnél találtunk traumát. $A 20$ betegből 17 versenysportoló volt, 2 szabadidő sportoló, 1 beteg pedig nem sportolt. A sportágak közül domináltak a küzdősportok (5 beteg), a 3 úszó, 2-2 vízilabdázó és tornász mellett 1-1 kézilabdázó, röplabdázó, vívó, kajakos, testépítő, táncos és futó szerepelt. A mútét minden esetben artroszkópos labrum refixáció volt, 6 betegnél egyidőben az első és hátsó labrum refixációját is el kellett végeznünk (I. táblázat).

A vizsgálat során a betegek szubjektív véleményét, a munkába és a sportba való visszatérést regisztráltuk, fizikális és röntgenvizsgálat is történt. Az utánvizsgálatot a Rowe-féle instabilitás és az ASES (American Shoulder and Elbow Surgeons Standardized Shoulder Assessment Form) pontrendszer segítségével végeztük el. A fizikális vizsgálat során vizsgáltuk a vállízület mozgásait, a rotátor köpeny erejét, az apprehenziós és az addukciós-berotációs tesztet és a humerusfej transzlációját. Betegeinknél kétirányú röntgenvizsgálatot (valódi $A P$ és axillaris felvételek) végeztünk. 


\section{I. táblázat A betegek adatai}

\begin{tabular}{|c|c|c|c|c|c|c|}
\hline Beteg & Nem & $\begin{array}{l}\text { Kor (év) } \\
\text { mütétkor }\end{array}$ & $\begin{array}{c}\text { Oldal/ } \\
\text { domináns }\end{array}$ & Mütét & Sportág/szint & Trauma \\
\hline 1. & nő & 17 & $J / D$ & $\mathrm{H}$ & $\begin{array}{c}\text { Tánc/ } \\
\text { versenyszerű }\end{array}$ & Igen \\
\hline 2. & ffi & 20 & $\mathrm{~B} / \mathrm{N}$ & $\mathrm{E}+\mathrm{H}$ & $\begin{array}{l}\text { Thai box/ } \\
\text { versenyszerü }\end{array}$ & Igen \\
\hline 3. & nő & 16 & $J / D$ & $\mathrm{H}$ & Nem sportol & Igen \\
\hline 4. & nő & 20 & $J / D$ & $\mathrm{H}$ & $\begin{array}{c}\text { Kajak/ } \\
\text { versenyszerű }\end{array}$ & Igen \\
\hline 5. & nő & 17 & $B / D$ & $\mathrm{E}+\mathrm{H}$ & $\begin{array}{c}\text { Vízilabda/ } \\
\text { versenyszerű }\end{array}$ & Igen \\
\hline 6. & nő & 21 & $J / D$ & $\mathrm{H}$ & $\begin{array}{c}\text { RG / } \\
\text { versenyszerű }\end{array}$ & Igen \\
\hline 7. & ffi & 20 & $\mathrm{~J} / \mathrm{N}$ & $\mathrm{H}$ & $\begin{array}{c}\text { Torna / } \\
\text { versenyszerű }\end{array}$ & Nem \\
\hline 8. & nő & 17 & $\mathrm{~J} / \mathrm{N}$ & $\mathrm{E}+\mathrm{H}$ & $\begin{array}{l}\text { Kézilabda / } \\
\text { válogatott }\end{array}$ & Igen \\
\hline 9. & nő & 16 & $\mathrm{~J} / \mathrm{D}$ & $\mathrm{H}$ & $\begin{array}{c}\text { Úszás / } \\
\text { versenyszerű }\end{array}$ & Nem \\
\hline 10. & nő & 15 & $\mathrm{~B} / \mathrm{N}$ & $\mathrm{H}$ & $\begin{array}{c}\text { Úszás / } \\
\text { versenyszerű }\end{array}$ & Nem \\
\hline 11. & nő & 35 & $\mathrm{~J} / \mathrm{D}$ & $\mathrm{E}+\mathrm{H}$ & $\begin{array}{l}\text { Vívás / } \\
\text { válogatott }\end{array}$ & Nem \\
\hline 12. & nő & 20 & $J / D$ & $\mathrm{H}$ & $\begin{array}{c}\text { Röplabda / } \\
\text { versenyszerű }\end{array}$ & Igen \\
\hline 13. & ffi & 21 & $J / D$ & $\mathrm{H}$ & $\begin{array}{l}\text { Úszás / } \\
\text { válogatott }\end{array}$ & Nem \\
\hline 14. & ffi & 24 & $\mathrm{~J} / \mathrm{D}$ & $\mathrm{E}+\mathrm{H}$ & $\begin{array}{l}\text { Birkózás / } \\
\text { válogatott }\end{array}$ & Igen \\
\hline 15. & nő & 14 & $\mathrm{~J} / \mathrm{D}$ & $\mathrm{H}$ & $\begin{array}{c}\text { Karate / } \\
\text { versenyszerű }\end{array}$ & Igen \\
\hline 16. & ffi & 19 & $J / D$ & $\mathrm{H}$ & $\begin{array}{c}\text { Karate / } \\
\text { versenyszerű }\end{array}$ & Igen \\
\hline 17. & nő & 20 & $\mathrm{~J} / \mathrm{N}$ & $\mathrm{H}$ & $\begin{array}{l}\text { Testépítés / } \\
\text { szabadidő }\end{array}$ & Igen \\
\hline 18. & ffi & 19 & $J / D$ & $\mathrm{H}$ & $\begin{array}{c}\text { Kung-fu / } \\
\text { versenyszerű }\end{array}$ & Igen \\
\hline 19. & ffi & 28 & $\mathrm{~B} / \mathrm{N}$ & $\mathrm{E}+\mathrm{H}$ & $\begin{array}{l}\text { Futás / } \\
\text { szabadidő }\end{array}$ & Igen \\
\hline 20. & nő & 18 & $\mathrm{~J} / \mathrm{D}$ & $\mathrm{H}$ & $\begin{array}{c}\text { Vízilabda / } \\
\text { versenyszerű }\end{array}$ & Igen \\
\hline
\end{tabular}




\section{MÜTÉTI TECHNIKA}

A mútéteket narcosisban, oldalfekvésben, körülbelül 45 fokos abdukciós helyzetben felfüggesztett karral végezzük. Standard vállízületi artroszkópiát követően határozzuk meg a patológiás elváltozásokat, a mútéti terv pontos felállítása érdekében (1. a ábra). A hátsó behatolást körülbelül $1 \mathrm{~cm}$-rel distalisabban és 1-2 cm-rel laterálisabban helyezzük el a standard hátsó behatolástól, így biztosítva, hogy megfelelő szögben helyezkedjen el a hátsó glenoidalis peremhez a horgonyok behelyezéséhez (1. $b$ ábra). Az elülső behatolás rutinszerűen a subscapularis ín felett történik, hátsó stabilizálás esetén még feljebb, általában a biceps ín mögött alakítjuk ki az optika számára a behatolásunkat (1. c ábra). Amennyiben első és hátsó stabilizálás is szükséges, először az elülső glenoid perem debridementjét, a labrum mobilizálását végezzük el, majd szükség szerint horgonyok segítségével a leszakadt labrum tok - alsó glenohumeralis szalag komplexet a cavitas glenoidalis elülső pereméhez rögzítjük. Ezt követően portált váltva a hátsó glenoidalis peremen hasonló módon járunk el. Fontos, hogy a hátsó glenoidalis perem megfelelő szögben való eléréséhez esetlegesen még egy hátsó behatolás lehet szükséges, kissé distális és laterális irányból (1. d ábra). Amennyiben eredetileg csak hátsó stabilizálást tervezünk, akkor már az optika bevezetésekor a standard behatolásunkat kissé distál és laterál felé eltolva megfelelő irányt kaphatunk. Az elülső behatolásunkat pedig szintén módosíthatjuk, amennyiben csak hátsó stabilizálás történik, célszerű inkább kicsit feljebb helyezni, ezáltal a kamerával jobban rálátunk a hátsó-alsó glenoidalis peremre.

A glenoidalis perem előkészítése, felfrissítése és a labrum mobilizálása hasonló módon történik, mint az elülső labrum refixátiók során, bár a hátsó labrum mobilizálhatósága általában különbözik attól, nincs olyan mértékű dislocatio, mint az elülső labrum sérüléseinél. Ezt követően helyezzük be a horgonyokat. A labrum - tok - hátsó glenohumeralis szalag felöltése technikailag nehezebb feladat, mint az elülső mútéteknél, aminek általában két oka van. Az egyik, hogy a kanül csak alig ér be az ízületbe és könnyebben kicsúszik, a másik pedig, hogy ha túl közel van a behatolás a glenoid peremhez, akkor kevesebb hely áll rendelkezésre az öltésnél szükséges manipulációhoz, nehezebb a tokból megfelelő mennyiséget felölteni. A tok felöltését kissé distálisan kezdjük meg, majd a labrum alatt a horgony magasságában vezetjük át a fonalat (2. a ábra). Időnként előfordult, hogy az öltés a tokon átvezetve extraartikulárisan helyezkedett el, és gyakorlatilag a csomózás extraartikulárisan történt, csak a végső állapotot tudtuk ellenőrizni. A csomózáshoz csúszó csomót alkalmazunk, melyet kiegészítünk $3 \mathrm{db}$ fél csomóval. Fontos, hogy a csomó a felöltött tok mögé és ne az ízületi felszín felé kerüljön, így egyrészt a felöltött tokot rászorítja a glenoid pereméhez, másrészt elkerüljük, hogy a csomó az ízfelszínen bármilyen irritációt okozzon (2. $b$ ábra).

A mútétet követően 0 fokos rotációs helyzetben kartartót helyezünk fel, a csukló és könyöktornát közvetlen a mútétet követően megkezdjük. A rögzítés ideje 4 hét, ezt követően a mozgásterjedelem visszaállítására gyógytorna kezdődik, de addukció-berotáció végzését csak 8 hét után engedjük. Ezt követően izomerősítő és propriocepciót javító gyakorlatok következnek, sportterhelés 6 hónap után végezhető (I. táblázat). 


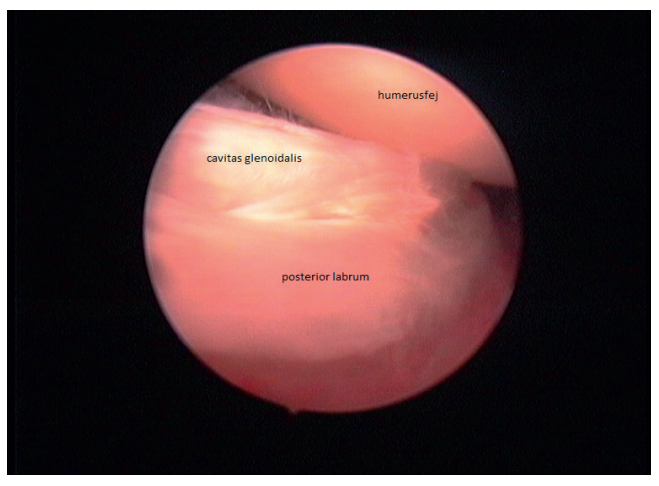

1. a ábra Hátsó labrum szakadás artroszkópos képe

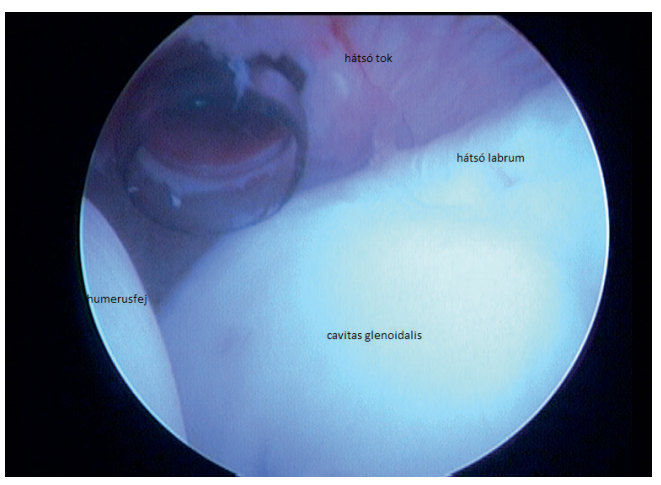

1. c ábra: Posterior portal elhelyezkedése

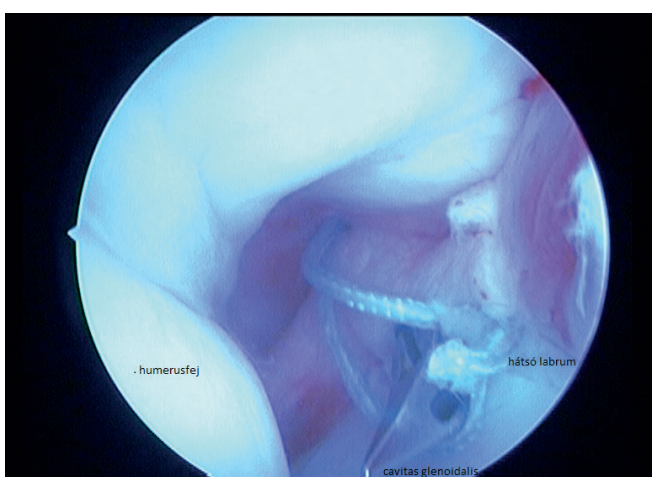

2. a ábra: A labrum és a tok átöltése

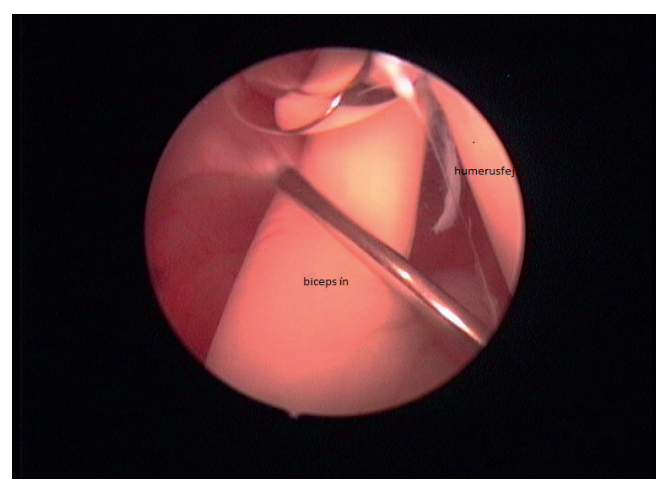

1. b ábra: Antero-superior behatolás

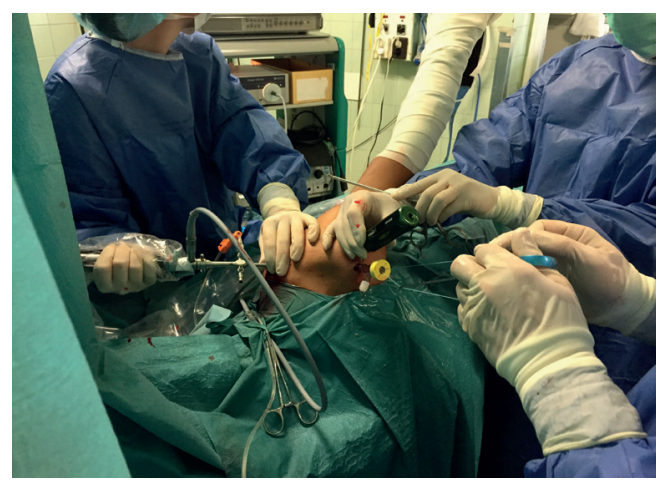

1. d ábra: Két hátsó behatolás is alkalmazható

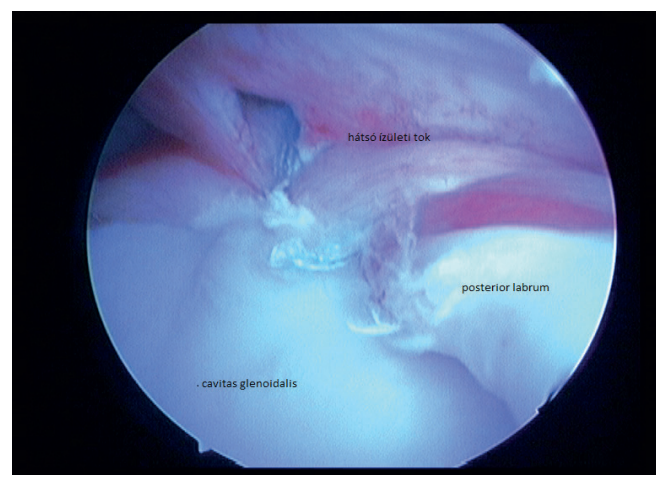

2. b ábra: Rekonstrukció utáni állapot 


\section{EREDMÉNYEK}

Az átlagos utánvizsgálati idő 37,7 hónap (9-74) volt. A Rowe pontrendszerrel vizsgálva a 14 betegből 11-nél találtunk kiváló, két betegnél pedig jó eredményt. Az ASES pontrendszer szerint átlagosan 88 (67-100) pontot értek el betegeink (II. táblázat).

A 14 betegből mindössze egy beteg számolt be egy alkalommal bekövetkezett subluxáció érzésről, a fizikális vizsgálat során negatív apprehenziós és negatív addukció-berotációs tesztet találtunk minden betegnél. A mozgástartomány vizsgálata során 4 betegnél találtunk minimális berotációs elmaradást, az egyéb mozgásoknál teljes volt a mozgástartomány.

A 13 sportoló közül hatan azonos szinten (46\%), hárman alacsonyabb szinten (23\%) folytatták sporttevékenységüket, ketten más sportágat választottak, míg ketten abbahagyták a versenyzést. A 13-ból összesen egy betegnek kellett a vállpanaszai miatt befejeznie a versenysportot.

A radiológiai vizsgálat során meggyőződhettünk a horgonyok elhelyezkedéséről. Ízületi arthrosist nem találtunk egy esetben sem, de ez a fiatal életkor és a rövid utánvizsgálati idő miatt nem is volt várható (3. ábra).

Mútéteink során két szövődmény fordult elő. Az egyik betegnél a posztoperatív röntgenfelvételen az egyik horgonycsavar kimozdulása volt látható, ezért reoperáció történt, amelynek során a kimozdult horgonycsavart az ízületből eltávolítottuk. Másik szövődményünk a nervus axillaris körül kialakult posztoperatív hegesedés volt, aminek következtében nagyfokú deltaizom hypotrophia alakult ki. Más intézetben végzett reoperáció során megtörtént a neurolysis, melyet követően a beteg panaszmentesen gyógyult.

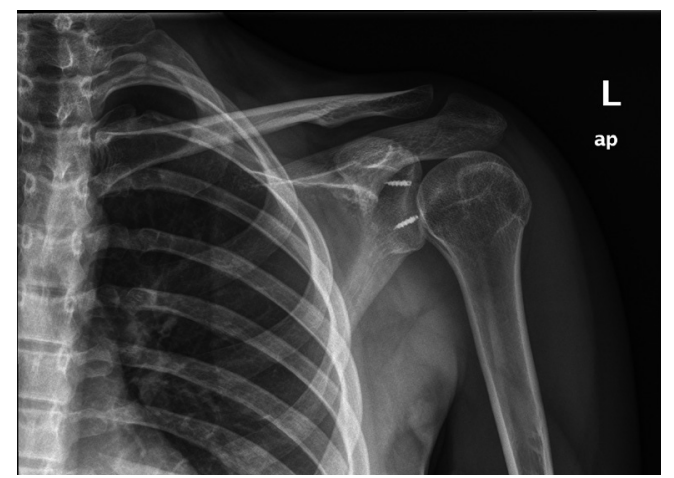

3. ábra

Posztoperativ röntgenfelvételek

a) Mütét után 3 hónappal

b) Mútét után 12 hónappal 
II. táblázat Posztoperativ eredmények

\begin{tabular}{|c|c|c|c|c|c|c|}
\hline & $\begin{array}{l}\text { Sportba való } \\
\text { visszatérés }\end{array}$ & Rowe & ASES & Fájdalom & Instabilitás & Funkció \\
\hline 1. & Abbahagyta & 75 - jó & 83,33 & enyhe & nincs & $\begin{array}{l}\text { minimális } \\
\text { elmaradás }\end{array}$ \\
\hline 2. & $\begin{array}{l}\text { Azonos } \\
\text { szinten }\end{array}$ & 95 - kiváló & 95 & enyhe & nincs & teljes \\
\hline 3. & Nem sportol & 100 - kiváló & 100 & nincs & nincs & teljes \\
\hline 4. & $\begin{array}{l}\text { Alacsonyabb } \\
\text { szinten }\end{array}$ & 75 - Jó & 66,66 & terhelésre: enyhe & nincs & $\begin{array}{l}\text { minimális } \\
\text { elmaradás }\end{array}$ \\
\hline 5. & $\begin{array}{l}\text { Abbahagyta - } \\
\text { egyéb okból }\end{array}$ & 95 - kiváló & 83,33 & enyhe & nincs & teljes \\
\hline 6. & $\begin{array}{l}\text { Más sportág - } \\
\text { egyéb okból }\end{array}$ & 90 - kiváló & 76,66 & $\begin{array}{l}\text { terhelésre: } \\
\text { közepes }\end{array}$ & nincs & $\begin{array}{l}\text { minimális } \\
\text { elmaradás }\end{array}$ \\
\hline 7. & $\begin{array}{l}\text { Más sportág } \\
\text { - röplabda }\end{array}$ & 90 - kiváló & 88,33 & enyhe & nincs & $\begin{array}{l}\text { minimális } \\
\text { elmaradás }\end{array}$ \\
\hline 8. & $\begin{array}{l}\text { Azonos } \\
\text { szinten }\end{array}$ & 100 - kiváló & 100 & nincs & nincs & teljes \\
\hline 9. & $\begin{array}{l}\text { Alacsonyabb } \\
\text { szinten }\end{array}$ & 60 - közepes & 85 & nincs & $\begin{array}{l}\text { subluxatio } \\
1 \mathrm{x}\end{array}$ & teljes \\
\hline 10. & $\begin{array}{l}\text { Alacsonyabb } \\
\text { szinten }\end{array}$ & 95 - kiváló & 98,33 & nincs & nincs & teljes \\
\hline 11. & $\begin{array}{l}\text { Azonos } \\
\text { szinten }\end{array}$ & 95 - kiváló & 80 & $\begin{array}{c}\text { enyhe } \\
\text { (hyalinkárosodás) }\end{array}$ & nincs & teljes \\
\hline 12. & $\begin{array}{l}\text { Azonos } \\
\text { szinten }\end{array}$ & 100 - kiváló & 100 & nincs & nincs & teljes \\
\hline 13. & $\begin{array}{l}\text { Azonos } \\
\text { szinten }\end{array}$ & 100 - kiváló & 100 & nincs & nincs & teljes \\
\hline 14. & $\begin{array}{l}\text { Azonos } \\
\text { szinten }\end{array}$ & 90 - kiváló & 81,66 & enyhe & nincs & teljes \\
\hline
\end{tabular}




\section{MEGBESZÉLÉS}

A vállízületi hátsó instabilitás egyre gyakrabban előforduló elváltozás, felismerése sok esetben nehézségekkel jár. $\mathrm{Az}$ irodalomban korábban a vállízületi instabilitások mindössze 2-5\%-t találták hátsó instabilitásnak, de az utóbbi években az incidenciája emelkedését figyelték meg, ami elsősorban a fiatal, aktív korosztályt érint $(4,13,17,18,19,24)$. A kialakulásában az egyszeri trauma mellett főleg sportolóknál a krónikus túlterhelésnek, illetve az ismétlődő mikrotraumáknak van jelentős szerepe $(14,17,24,27)$. A klinikai tünetek is igen változatosak, instabilitásról a betegek többsége nem számol be, jellemzőbb a terhelés közben, a váll addukciós és berotációs helyzetében jelentkező vállfájdalom (3, 19, 24). A diagnózis helyes felállítását segítik a képalkotók, az MR vizsgálatnak lényeges szerepe van a mútéti terv felállításában (24). A konzervatív kezelés gyakran nem ad kielégítő eredményt, a sportolók nem képesek azonos szinten folytatni sporttevékenységüket $(7,11,21)$.

Eredménytelen konzervatív kezelés esetén mútéti megoldás válik szükségessé $(12,22)$, az irodalomban a nyitott mútétekkel szemben az artroszkópos technikák váltak elfogadottabbá és eredményesebbé, bár az esetek kisebb száma miatt a mútét technikailag nehezebb (8, $10,11,21,25)$. A mútétek során fontos a kóros anatómiai elváltozás meghatározása és ennek kezelése, mivel a hátsó instabilitás hátterében számos patológia lehet, így a hátsó labrum sérülése vagy lecsiszolódása, a hátsó tok sérülése, tágulata és a rotátor intervallum lazasága mellett akár az elülső struktúrák sérüléseivel is találkozhatunk $(2,19,22)$. A korábban alkalmazott thermál shrinkage nem javasolt eljárás.

A mútéthez általában az oldalfekvő testhelyzetet helyezik előtérbe szemben a beach chair pozícióval, osztályunkon is oldalfekvésben végezzük a beavatkozást $(2,5,15,22$, 23). A mútét során az egyik legfontosabb lépés a hátsó behatolásnak a horgonybehelyezés szempontjából való ideális elhelyezése. Erre két megoldás van, az egyik, egy a standard portáltól distálisan és laterálisan elhelyezkedő kiegészítő hátsó behatolás alkalmazása, ami kiküszöbölhető, ha az eredeti hátsó behatolást $1 \mathrm{~cm}$-rel distálisabban és 1-2 cm-rel laterálisabban helyezzük el $(9,15,22,23)$. Saját gyakorlatunk során a hátsó behatolást kissé distálisabban és laterálisabban helyezzük el, majd a sérülés pozíciójától és kiterjedésétől függően a mútét során döntünk arról, hogy alkalmazunk-e még egy hátsó behatolást. A kiegészítő posterolaterális behatolás az anatómiai tanulmányok szerint igen közel helyezkedik el a nervus axillárishoz, ami a legközelebb a glenoid peremhez 6 óra pozícióban fut.

A műtét során a hátsó labrum sérülése esetén horgonyok behelyezésével történik a labrum refixációja, melyet a laza hátsó tok plicatiójával egészítünk ki. A labrum sérülése gyakran nem a teljes leszakadását jelenti, több alkalommal inkább jelentős felrostozódás figyelhető meg a posteroinferior labrum szakaszon, melyet más szerzők is megfigyeltek (9, $15,27)$.

$\mathrm{Az}$ irodalomban található posztoperatív eredmények alapján az artroszkópos stabilizálás jó eredményeket ad mind a recidíva $(2,4-8 \%)$, mind a sporthoz való visszatérés szempontjából $(1,2,6,15,16,22,27)$, mégis a dobó sportolók alacsonyabb arányban képesek az eredeti szinten visszatérni sportágukhoz $(10,16,20)$. Osztályunk eredményei ezzel összhangban vannak, mindössze egy betegnél tapasztaltunk ismételt subluxáció érzést és a sporthoz való visszatérést tekintve is jó eredményeket értünk el.

Összességében a fiatal aktív populációnál hátsó vállízületi instabilitás incidenciájának emelkedése figyelhető meg. Az utóbbi években alkalmazott artroszkópos mútéti technika jelentősen javította a korábban akár a nyitott, akár a kezdeti artroszkópos mútétekkel elért eredményeket. A pontos intraartikuláris patológia alapján elvégzett artroszkópos beavatkozások révén a hátsó vállízületi instabilitás eredményesen kezelhető. 


\section{IRODALOM}

1. Arner J. W., McClincy M. P., Bradley J. P.: Arthroscopic stabilization of posterior shoulder instability is successful in american football. Arthroscopy. 2015. 31. (8): 1466-1471. http://dx.doi.org/10.1016/i.arthro.2015.02.022

2. Bahk M. S., Karzel R. P., Snyder S. J.: Arthroscopic posterior stabilization and anterior capsular plication for recurrent posterior glenohumeral instability. Arthroscopy. 2010. 26. (9): 1172-1180. http://dx.doi.orq/10.1016/i.arthro.2010.06.016

3. Blasier R. B., Soslowsky L. J., Malicky D. M., Palmer M. L.: Posterior glenohumeral subluxation: active and passive stabilization in a biomechanical model. J. Bone Joint Surg. Am. 1997. 79. (3): 433-440.

4. Bottoni C. R., Franks B. R., Moore J. H., DeBerardino T. M., Taylor D. C., Arciero R. A.: Operative stabilization of posterior shoulder instability. Am. J. Sports Med. 2005. 33. 996-1002. http://dx.doi.org/10.1177/0363546504271509

5. Bradley J. P., Forsythe B., Mascarenhas R.: Arthroscopic management of posterior shoulder instability: diagnosis, indications, and technique. Clin. Sports Med. 2008. 27. (4): 649-670. http://dx.doi.orq/10.1016/i.csm.2008.06.001

6. Bradley J. P., McClincy M. P., Arner J. W., Tejwani S. G.: Arthroscopic capsulolabral reconstruction for posterior instability of the shoulder: a prospective study of 200 shoulders. Am. J. Sports Med. 2013. 41. (9): 2005-2014. http://dx.doi.orq/10.1177/0363546513493599

7. Burkhead W. Z. Jr., Rockwood C. A. Jr.: Treatment of instability of the shoulder with an exercise program. J. Bone Joint Surg. Am. 1992. 74. (6): 890-896.

8. Cheatham S. A., Mair S. D.: Arthroscopic technique for the evaluation and treatment of posterior shoulder instability. Orthopedics. 2009. 32. (3): 194. http://dx.doi.ora/10.3928/01477447-20090301-06

9. Ciccone W. J. 2nd: Arthroscopic posterior labral repair and capsular shift with a lateralized posterior portal. Arthrosc. Tech. 2013. 2. (4): e323-326. http://dx. doi.ora/10.1016/i.eats.2013.05.005

10. DeLong J. M., Jiang K., Bradley J. P.: Posterior instability of the shoulder: A systematic review and meta-analysis of clinical outcomes. Am. J. Sports Med. 2015. 43. (7): 1805-1817. http://dx.doi.org/10.1177/0363546515577622

11. Hawkins R. J., Koppert G., Johnston G.: Recurrent posterior instability (subluxation) of the shoulder. J. Bone Joint Surg. Am. 1984. 66. (2): 169-174.

12. Kim S. H., Park J. C., Park J. S., Oh I.: Painful Jerk Test: A predictor of success in nonoperative treatment of posteroinferior instability of the shoulder. Am. J. Sports Med. 2004. 32. 1849-1855. http://dx.doi.org/10.1177/0363546504265263

13. Kowalski M. S., Levine W. N.: Traumatic posterior glenohumeral dislocation: Classification, pathoanatomy, diagnosis and treatment. Orthop. Clin. North Am. 2008. 39. 519-533. http://dx.doi.org/10.1016/j.ocl.2008.05.008

14. Leivadiotou D., Ahrens P.: Arthroscopic treatment of posterior shoulder instability: A systematic review. Arthroscopy. 2015. 31. (3): 555-560. http://dx.doi.org/10.1016/j.arthro.2014.11.009

15. Lenart B. A., Sherman S. L., Mall N. A., Gochanour E., Twigg S. L., Nicholson G. P.: Arthroscopic repair for posterior shoulder instability. Arthroscopy. 2012. 28. (10): 1337-1343. http://dx.doi.org/10.1016/i.arthro.2012.03.011

16. McClincy M. P., Arner J. W., Bradley J. P.: Posterior shoulder instability in throwing athletes: A case-matched comparison of throwers and non-throwers. Arthroscopy. 2015. 31. (6): 1041-1051. http://dx.doi.org/10.1016/i.arthro.2015.01.016

17. Millet P. J., Clavert P., Hatch G. F. III., Warner J., P.: Recurrent posterior shoulder instability. J. Am. Acad. Orthop. Surg. 2006. 14. 464476. http://dx.doi.org/10.5435/00124635-200608000-00004

18. Owens B. D., Agel J., Mountcastle S. B., Cameron K. L., Nelson B. J.: Incidence of glenohumeral instability in collegiate athletics. Am. J. Sports Med. 2009. 37. 1750-1754. http://dx. doi.org/10.1177/0363546509334591

19. Provencher M. T., LeClere L. E., King S., McDonald L. S., Frank R. M., Mologne T. S., Ghodadra N. S., Romeo A. A.: Posterior instability of the shoulder: diagnosis and management. Am. J. Sports Med. 2011. 39. (4): 874-886. http://dx.doi.org/10.1177/0363546510384232

20. Radkowski C. A., Chhabra A., Baker C. L., Tejwani S. G., Bradley J. P.: Arthroscopic capsulolabral repair for posterior shoulder instability in throwing athletes compared with nonthrowing athletes. Am. J. Sports Med. 2008. 36. (4): 693-699. http://dx.doi.orq/10.1177/0363546508314426

21. Robinson C. M., Aderinto J.: Recurrent posterior shoulder instability. J. Bone Joint Surg. Am. 2005. 87. (4): $883-892$. http://dx.doi.org/10.2106/JBJS.D.02906

22. Savoie F. H. 3rd, Holt M. S., Field L. D., Ramsey J. R.: Arthroscopic management of posterior instability: evolution of technique and results. Arthroscopy. 2008. 24. (4): 389-396. $h$ ttp://dx.doi.org/10.1016/j.arthro.2007.11.004

23. Song D. J., Abrams J. F: Arthroscopic repair of posterior instability. Operat. Techn. Sports Med. 2014. 22. (1): 3-9. http://dx.doi.org/10.1053/i.otsm.2014.02.001

24. Song D. J., Cook J. B., Krul K. P., Bottoni C. R., Rowles D. J., Shaha S. H., Tokish J. M.: High frequency of posterior and combined shoulder instability in young active patients. J. Shoulder Elbow Surg. 2015. 24. (2): 186-190. http://dx.doi.org/10.1016/i.jse.2014.06.053

25. Van Tongel A., Karelse A., Berghs B., Verdonk R., De Wilde L.: Posterior shoulder instability: current concepts review. Knee Surg. Sports Traumatol. Arthrosc. 2011. 19. (9): 1547-1553. http://dx.doi.org/10.1007/s00167-010-1293-z

26. Wolf E. M., Eakin C. L.: Arthroscopic capsular plication for posterior shoulder instability. Arthroscopy. 1998. $14.153-163$. http://dx.doi.org/10.1016/S0749-8063(98)70034-9

27. Williams R. J. III., Strickland S., Cohen M., Altchek D. W., Warren R. F.: Arthroscopic repair for traumatic posterior shoulder instability. Am. J. Sports Med. 2003. 31. 203-209.

\section{Dr. Pavlik Attila}

1123 Budapest, Alkotás utca 48.

E-mail: pavlika@t-online.hu 